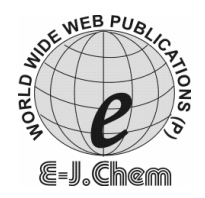

http://www.e-journals.net
ISSN: 0973-4945; CODEN ECJHAO

E-Journal of Chemistry

2010, 7(4), 1571-1577

\title{
Microwave-Assisted Synthesis of 3,5-Dibenzyl-4- amino-1,2,4-triazole and its Diazo Ligand, Metal Complexes Along with Anticancer Activity
}

\author{
ANJALI JHA*, Y L N MURTHY ${ }^{\S}$, G DURGA $^{\#}$ and T.T.SUNDARI \\ *Department of Chemistry, \\ Gitam Institute of Science, GITAM University, Rushikonda, India. \\ ${ }^{\S}$ Department of Organic Chemistry and FDW, Andhra University, India. \\ "Department of Chemistry, St Josephs College for Women, \\ Visakhapatnam, 530004, India. \\ NFMC, Bharatidasan University, Tiruchirapalli, 620024, India. \\ anjalimanishja@yahoo.com
}

Received 27 November 2009; Accepted 20 January 2010

\begin{abstract}
Synthesis of 3,5-dibenzyl-4-amino-1,2,4-triazole was accomplished via a conventional method as well as microwave irradiation method, followed by diazotization and coupling with 2,4-pentanedione. The dinucleating ligand was isolated and complexed with $\mathrm{Ni}(\mathrm{II}), \mathrm{Cu}(\mathrm{II})$ and $\mathrm{Ru}(\mathrm{III})$ chlorides. These complexes were screened on Jurkat, Raji \& PBMC cell lines for anticancer activity. Ruthenium complexes showed potential anticancer activities.
\end{abstract}

Keywords: 3,5-Dibenzyl-4-amino-1,2,4-triazole, Diazo ligand, Ni(II), Cu(II) and Ru(II) complexes, Anticancer activity.

\section{Introduction}

Chemistry is critical to drug discovery, especially at the lead optimization phase, but methods for the synthesis of organic compounds have remained essentially unchanged for decades. Since optimization time is usually very long with a very high manpower requirement, new ways to improve the efficiency, output and quality in this phase are always needed. One feasible solution is microwave assisted synthesis, which is in many ways superior to traditional heating; reactions are completed in minutes, yields are generally higher than those achievable by traditional means ${ }^{1}$. The application of microwave (MW) irradiation in organic synthesis has been the focus of considerable attention in recent years and is becoming an increasing popular technology $y^{2,3}$. The salient features of the microwave approach are the rapid reaction rates, cleaner reaction conditions and the operational simplicity. 
1,2,4-Triazole and its derivatives are found to be associated with various biological activities ${ }^{4}$. For example, fluconazole is used as an antimicrobial drug, while vorozole, letrozole and anastrozole are nonsteroidal used for treatment of cancer and loreclezole is used as an anticonvulsant ${ }^{5}$. Also 4-amino-1,2,4-triazoles are potentially good corrosion inhibitors ${ }^{6}$. These compounds can be prepared by the nucleophilic attack of hydrazine derivatives on nitriles ${ }^{7,8}$. Additionally, diazonium salts of heterocycles coupled with 2,4-pentanedione have been used as precursor in the synthesis of antimicrobial triazines".

Rosenberg's discovery ${ }^{10}$ of the important Pt-containing antitumor drug ciplatin led to the search for other metal ions that could complex with biomolecules and exhibit carcinostatic properties. Since the chemical nuclease activity of transition metal complexes was discovered in the $1980 \mathrm{~s}^{11}$ studying the interaction model and the mechanism of transition metal complexes with DNA and exploring the application of metal complexes in antineoplastic medication, molecular biology and bioengineering have become hotspots in recent years.

Based on the above literature precedents and importance of ligand-metal system, we chose to synthesize 3,5-disubstituted-4-amino-1,2,4-triazole by conventional means as well as Microwave irradiation method, followed by diazotization and coupled with 2,4-pentanedione. The ligand was further complexed with $\mathrm{Ni}(\mathrm{II}), \mathrm{Cu}(\mathrm{II})$ and $\mathrm{Ru}(\mathrm{III})$ chlorides and screened against cancerous cell lines.

\section{Experimental}

Melting points are uncorrected. IR spectra were recorded on Thermo Nicolet FT IR spectrophotometer at Andhra University, ${ }^{1} \mathrm{H}$ NMR spectra were taken on Perkin Elmer R-32, $90 \mathrm{MHz}$ in DMSO- $\mathrm{d}_{6}$ using TMS as internal reference at IICT, Hyderabad and ESR spectra were taken on Varian E 112 at room temperature and as well as liquid nitrogen temperature using DPPH as standard at IIT Chennai. Benzyl cyanide, hydrazine hydrate, ethylene glycol and 2,4-pentanedione were purchased from Across. All the solvents were of analytical grade and were distilled before use. Microwave irradiation was carried out using a domestic microwave oven. All the complexes were analyzed for the metal content by standard procedure. Elemental analyses were carried out at Micro Analytical Center at Andhra University. The HPLC was recorded using Shimadzu LC 6A with Shimpack silica gel column. Anticancer screening was done at department of Biotechnology, Mother Teresa Women's University, Kodaikanal, on Jurkat, Raji \& PBMC cell lines.

Synthesis of 3,5-dibenzyl-4-amino-1,2,4-triazole(2)

In conventional method of synthesis a mixture of benzyl cyanide ( $2 \mathrm{mmol})$, hydrazine hydrate $(1 \mathrm{mmol})$ and ethylene glycol $(5 \mathrm{~mL})$ were heated under reflux for $10 \mathrm{~h}$. After cooling $5 \mathrm{~mL}$ of $\mathrm{HCl}$ was added and again refluxed for $4 \mathrm{~h}, 3,5$-dibenzyl-4-amino-1,2,4triazole $(\mathbf{2})$ was isolated and characterized.

Two different MW reaction routes were adopted to synthesize 3,5-dibenzyl-4-amino1,2,4-triazole. In first method ${ }^{12}$ benzyl cyanide $(2 \mathrm{mmol})$ and hydrazine hydrate $(1 \mathrm{mmol})$ were irradiated under microwave irradiation in presence of ethylene glycol $(5 \mathrm{~mL})$ for $9 \mathrm{~min}$ at $300 \mathrm{~W}$.The product was worked up and dark pink colored dihydro-1,2,4,5-tetrazine (1), (Scheme 1) formed, which rearranges on treatment under acidic conditions into the 3,5dibenzyl 4-amino-1,2,4-triazole (2). In the second method ${ }^{13}$ benzyl cyanide $(2 \mathrm{mmol})$, hydrazine hydrate $(1 \mathrm{mmol})$, hydrazine dihydro chloride $(0.5 \mathrm{mmol})$ and ethylene glycol $(5 \mathrm{~mL})$ were mixed together and irradiated under microwave condition for $8 \mathrm{~min}$ at $250 \mathrm{~W}$. The addition of ethylene glycol led to form homogeneous solution and resulted the formation of (2) (Scheme 2) via intermediate (1) 


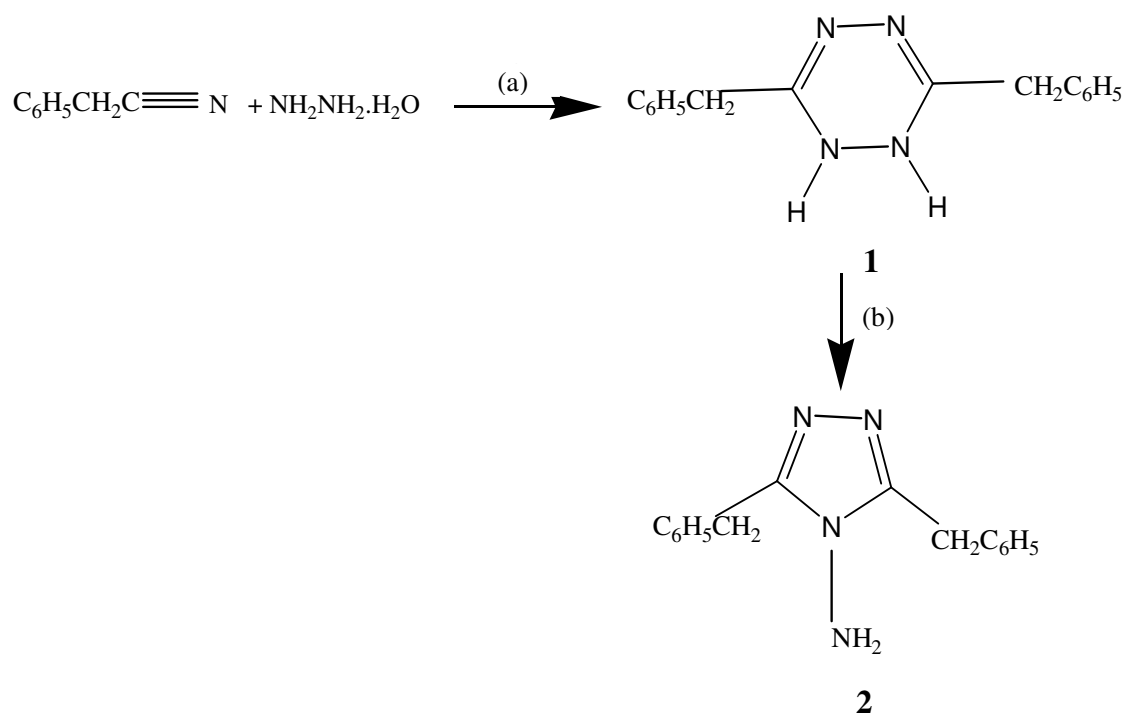

Scheme 1. Method 1, where: (a) $\mathrm{HOCH}_{2} \cdot \mathrm{CH}_{2} \mathrm{OH} / \mathrm{MW}, 9 \mathrm{~min}$; (b) $2 \mathrm{~mL} \mathrm{HCl} / \mathrm{MW}, 5 \mathrm{~min}$

Scheme 2. Method 2, where: (a) $\mathrm{NH}_{2} \mathrm{NH}_{2}$. $2 \mathrm{HCl}, \mathrm{HOCH}_{2} \cdot \mathrm{CH}_{2} \mathrm{OH} / \mathrm{MW}, 8 \mathrm{~min}$; (b) Nil

\section{Synthesis of ligand}

Substituted amino triazole (2) of $0.1 \mathrm{~mol}$ was dissolved in $5 \mathrm{~mL}$ conc $\mathrm{HCl}$ and cooled below $-5^{0}$ to $-10{ }^{0} \mathrm{C}$, diazotized ${ }^{9}$ by the addition of cold $\mathrm{NaNO}_{2}\left(1.5 \mathrm{~g}\right.$ in $\left.10 \mathrm{~mL} \mathrm{H}_{2} \mathrm{O}\right)$ solution. In the resulting solution of diazonium salt, a cold solution of 2,4-pentanedione $(0.1$ mol) containing sodium acetate $(5 \mathrm{~g})$ in water $(10 \mathrm{~mL})$ was added. The mixture was stirred for $3 \mathrm{~h}$ at $20{ }^{\circ} \mathrm{C}$. The solid product formed was collected by filtration and crystallized from ethyl alcohol. The isolated ligand (Figure 1) was characterized by various spectral methods.

\section{General procedure for the preparation of metal complexes}

In the ethanolic solution of ligand $(1 \mathrm{mmol})$, an ethanolic solution of respective metal salts ( 2 mmol each $\mathrm{NiCl}_{2} \cdot 6 \mathrm{H}_{2} \mathrm{O} ; \mathrm{CuCl}_{2} \cdot \mathrm{H}_{2} \mathrm{O}$ and $\mathrm{RuCl}_{3} \cdot 3 \mathrm{H}_{2} \mathrm{O}$ ) was added ${ }^{14}$ separately drop wise while stirring followed by the addition of 2-3 drops of $\left(\mathrm{C}_{2} \mathrm{H}_{5}\right)_{3} \mathrm{~N}$. The contents of the mixture were refluxed for 3-4 h. The crystalline substance thus obtained were filtered and washed successively with ethanol and ether and dried in vacuum.

\section{Study of cytotoxicity}

Anticancer activity testing was performed by dye exclusion method. Bioactivity assay was performed in a 96 well tissue culture plate (Greiner, Germany). Various concentrations of the compounds ranging from $25 \mathrm{ng}-150 \mathrm{ng}$ were made. A constant number of cancerous (Jurkat, Raji \& PBMC) cell suspensions and a constant volume of the complete media were added into each well. Desired concentrations of the compounds were added into each well and the volume was made constant, using complete media. Negative (solvent used for dissolving the compound) and positive (known immunomodulator) controls were also maintained. The plate was incubated at $37{ }^{\circ} \mathrm{C}$ in $\mathrm{CO}_{2}$ incubator with $5 \% \mathrm{CO}_{2}$. The numbers of live cells were counted after every $12 \mathrm{~h}$ by using inverted phase contrast microscope (Nikon TM) and the Newbauer's counting chamber by dye exclusion method. 


\section{Results and Discussion}

Recently, organic transformation accelerated under solvent free microwave irradiation condition gained wide popularity due to many practical advantages associated with enhanced reaction rates, high yields; improve selectivity ${ }^{12}$ and environment friendly reaction condition ${ }^{13}$ in tune with green chemistry. Keeping these facts in consideration, we adopted Microwave (MW) synthesis, for the first time. A symmetrically 3,5-dibenzyl-4-amino-1,2,4triazole was quickly prepared by the reaction of aromatic nitrile and hydrazine dihydrochloride in the presence of an excess of hydrazine hydrate in the ethylene glycol under microwave irradiation. In the first method ${ }^{12}$ benzyl cyanide $(2 \mathrm{mmol})$ and hydrazine hydrate $(1 \mathrm{mmol})$ were irradiated in presence of ethylene glycol $(5 \mathrm{~mL})$ for 9 min at $300 \mathrm{~W}$. The product was worked up and dark pink coloured dihydro-1,2,4,5-tetrazine-3,5-dibenzyl (1), (Scheme 1) formed, which rearranges itself on treatment under acidic conditions into the 3,5-dibenzyl-4-amino-1,2,4-triazole (2). In the second method ${ }^{13}$ benzyl cyanide, hydrazine hydrate, hydrazine dihydro chloride and ethylene glycol were mixed together and irradiated under microwave condition for $8 \mathrm{~min}$ at $250 \mathrm{~W}$. In conventional method, same ratio of reactants were mixed and heated under reflux for $10 \mathrm{~h}$. The isolated product compound 2 from both the MW methods and conventional method was compared, identical TLC and melting point $\left(142{ }^{0} \mathrm{C}\right)$ was found. The synthesized 3,5-dibenzyl-4-amino-1,2,4-triazole was subjected for diazotization and coupled with 2,4-pentanedione. The ligand Figure 1 were characterized by spectral methods. The analytical data of the ligand and their metal complexes are given in Table 1 .

Table 1. Physical and Analytical data of Synthesized Compound

\begin{tabular}{|c|c|c|c|c|c|c|c|}
\hline \multirow{2}{*}{ S. No. } & \multirow{2}{*}{ Compound } & \multirow{2}{*}{ Colour/MP ${ }^{0} \mathrm{C}$} & \multicolumn{5}{|c|}{ Found (Calcd)\% } \\
\hline & & & $\mathrm{C}$ & $\mathrm{H}$ & $\mathrm{N}$ & M & $\mathrm{Cl}$ \\
\hline 1 & $\mathrm{C}_{16} \mathrm{H}_{16} \mathrm{~N}_{4}$ & light & $\begin{array}{c}72.75 \\
(72.72)\end{array}$ & $\begin{array}{c}6.09 \\
(6.06)\end{array}$ & $\begin{array}{c}21.25 \\
(21.21)\end{array}$ & - & - \\
\hline 2 & $\mathrm{C}_{21} \mathrm{H}_{21} \mathrm{~N}_{5} \mathrm{O}_{2}(\mathbf{L})$ & 0 & $\begin{array}{c}67.32 \\
(67.20)\end{array}$ & $\begin{array}{c}5.06 \\
(5.61)\end{array}$ & $\begin{array}{c}18.62 \\
(18.66)\end{array}$ & - & - \\
\hline 3 & {$\left[\mathrm{Ni}(\mathrm{L}) \mathrm{Cl}\left(\mathrm{H}_{2} \mathrm{O}\right)_{3}\right]$} & leafy & $\begin{array}{c}48.20 \\
(48.16)\end{array}$ & $\begin{array}{c}5.19 \\
(5.16)\end{array}$ & $\begin{array}{c}13.40 \\
(13.37)\end{array}$ & $\begin{array}{c}11.31 \\
(11.22)\end{array}$ & $\begin{array}{c}6.82 \\
(6.78)\end{array}$ \\
\hline 4 & {$\left[\mathrm{Cu}(\mathrm{L}) \mathrm{Cl}\left(\mathrm{H}_{2} \mathrm{O}\right)_{3}\right]$} & Leafy & $\begin{array}{c}47.62 \\
(47.72)\end{array}$ & $\begin{array}{c}5.16 \\
(5.11)\end{array}$ & $\begin{array}{c}13.28 \\
(13.25)\end{array}$ & $\begin{array}{c}12.23 \\
(12.03)\end{array}$ & $\begin{array}{c}6.77 \\
(6.72)\end{array}$ \\
\hline 5 & {$\left[\mathrm{Ru}(\mathrm{L}) \mathrm{Cl}\left(\mathrm{H}_{2} \mathrm{O}\right)_{3}\right]$} & Black & $\begin{array}{c}44.50 \\
(44.55)\end{array}$ & $\begin{array}{c}4.72 \\
(4.77)\end{array}$ & $\begin{array}{c}12.32 \\
(12.37)\end{array}$ & $\begin{array}{c}-- \\
(17.87)\end{array}$ & $\begin{array}{c}6.31 \\
(6.27)\end{array}$ \\
\hline
\end{tabular}

The comparative IR spectral study of the ligands and their metal complexes reveal the interesting coordination mode of the ligand during complex formation. The disappearance of peaks in the region $3377 \mathrm{~cm}^{-1}$ for ligand indicated that the $\mathrm{NH}_{2}$ group of substituted triazole is changed to $\mathrm{N}=\mathrm{N}$ in the formation of ligand ${ }^{15}$ which was further supported by comparing NMR spectra of substituted triazole and ligand The peaks 1708 and 1421 respectively were assigned to $\mathrm{C}=\mathrm{O}$ and $\mathrm{N}=\mathrm{N}$, which were shifted to lower frequencies ${ }^{15}$ in the IR spectra of all metal complexes, indicating the coordination with ligand. The metal complexes show new bands in the regions $480-450 \mathrm{~cm}^{-1}$ and 350-320 $\mathrm{cm}^{-1}$, which are due to the formation of M-N and M-O bonds ${ }^{16}$ respectively.

The ${ }^{1} \mathrm{H}$ NMR spectra of 3,5-dibenzyl-4-amino-1,2,4-triazole(2) and ligand (Figure 1) were recorded in $\mathrm{CDCl}_{3}$. The substituted triazole displayed multiplets in the region $\delta$ 7.4-7.2 due to aromatic protons, which remains same position in the ligand (Figure 1); $\delta 4.4\left(\mathrm{NH}_{2}\right)$ and $4.0\left(\mathrm{CH}_{2}\right)$ protons. The disappearance of $\mathrm{NH}_{2}$ peak and presence $\mathrm{CH}_{3}$ at 1.5 indicated that it 
was diazotized and coupled with acetyl acetone ${ }^{14}$. In the ${ }^{13} \mathrm{C}$ NMR of substituted triazole showed peaks at $31\left(\mathrm{CH}_{2}\right) ; 128,129,130,135$ for aryl carbons; 155 for triazole ring carbon. However in ligand extra peaks were observed at $15,55,180 \mathrm{ppm}$ were assigned to $\left(\underline{\mathrm{CH}_{3}}, \underline{\mathrm{C}} \mathrm{H} \& \underline{\mathrm{CO}}\right.$ of 2,4 pentanedione) Poor solubility of metal complexes restricted us to record NMR spectra.

\section{ESR Spectra}

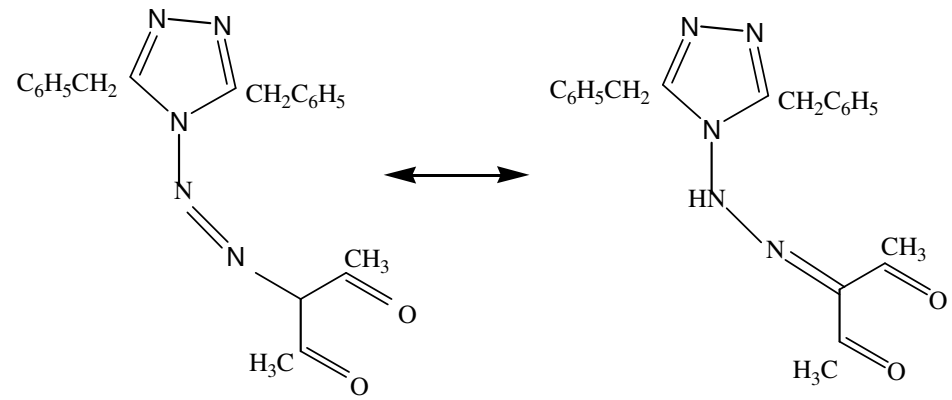

Figure 1

The ESR spectra of $\mathrm{Cu}(\mathrm{II})$ complex of the ligand was recorded at room temperature (RT) and liquid nitrogen temperature (LNT).The spin Hamiltonian parameters, calculated from the spectra is given in Table 2 .The powder state spectra of the complex $\left[\mathrm{Cu}(\mathrm{L}) \mathrm{Cl}\left(\mathrm{H}_{2} \mathrm{O}\right)_{3}\right]$ at $\mathrm{RT}$ and LNT showed four equally spaced lines as expected for $\mathrm{Cu}(\mathrm{II})$ ion showing $\mathrm{g}_{\|}>\mathrm{g}_{\perp}$ ,however it is more clear in LNT spectra. The values are supportive of octahedral geometry around metal ${ }^{17}$. Basic spectral characteristics at both temperatures are the same with slightly better resolution ${ }^{18}$ at LNT. The half field signal was not observed in any spectra is indicated that there is no $\mathrm{Cu}-\mathrm{Cu}$ interaction between the complex. On the basis of above spectral studies and metal estimation metal complexes were assigned to octahedral geometry Figure 2 .

Table 2. Powder Spin-Hamiltonian parameters of $\mathrm{Cu}(\mathrm{II})$ complex

\begin{tabular}{rccc}
\hline Complex & $\mathrm{g}_{\|}$ & $\mathrm{g}_{\perp}$ & $\mathrm{A}_{\|}$ \\
\hline$\left[\mathrm{Cu}(\mathrm{L}) \mathrm{Cl}\left(\mathrm{H}_{2} \mathrm{O}\right)_{3}\right]$ & & & 165 \\
$\mathrm{RT}$ & 2.241 & 2.023 & 160 \\
LNT & 2.322 & 2.042 & \\
\hline
\end{tabular}

$R T=$ room temperature; $L N T=$ liquid nitrogen temperature<smiles>CC(C=O)ON=C=Nn1cnnc1</smiles>

$\mathrm{OH}_{2}$

where $\mathrm{M}=\mathrm{Ni}, \mathrm{Cu}, \mathrm{Ru}$

Figure 2. Structure of metal complexes 


\section{Study of cytotoxicity}

Simultaneously, our objective of synthesis of metal ligand complexes and also to study their activity, the compound YLN-AJ-1, 2 \& 3 (Table 3) were screened on Jurkat, Raji \& PBMC cell lines for anticancer activity. The studies indicated that YLN-AJ-3 (Ru complex of Ligand) exhibited anti-cancer activity in vitro, in nanogram scale. The experimental results are enclosed below in Table 3. It is also indicated that $\mathrm{Ni}(\mathrm{II})$ and $\mathrm{Cu}(\mathrm{II})$ complexes of ligand were not active against Jurkat and Raji cell lines while it showed cytotoxicity at $50 \& 100 \mathrm{ng}$ against Jurkat and Raji cancer cell lines while it is non toxic even at $100 \mathrm{ng}$ against PBMC cell line. Further sensitive studies are in process.

Table 3. Experimental results for samples screened on cancer cells

\begin{tabular}{|c|c|c|c|c|}
\hline S.No. & Sample name & Jurkat & Raji & PBMC \\
\hline 1 & $\begin{array}{l}\text { YLN-AJ-1 } \\
{\left[\mathrm{Ni}(\mathrm{L}) \mathrm{Cl}\left(\mathrm{H}_{2} \mathrm{O}\right)_{3}\right]}\end{array}$ & Not active & Not active & $\begin{array}{l}\text { Cytotoxic } \\
\left(200 \mathrm{ng}^{*}\right)\end{array}$ \\
\hline 2 & $\begin{array}{l}\text { YLN-AJ-2 } \\
{\left[\mathrm{Cu}(\mathrm{L}) \mathrm{Cl}\left(\mathrm{H}_{2} \mathrm{O}\right)_{3}\right]}\end{array}$ & Not active & Not active & $\begin{array}{c}\text { Cytotoxic } \\
(150,200 \& 250 \mathrm{ng})\end{array}$ \\
\hline 3 & $\begin{array}{l}\text { YLN-AJ-3 } \\
{\left[\mathrm{Ru}(\mathrm{L}) \mathrm{Cl}\left(\mathrm{H}_{2} \mathrm{O}\right)_{3}\right]}\end{array}$ & $\begin{array}{l}\text { Toxic to cancer } \\
\text { cell line } \\
(50 \& 100 \mathrm{ng})\end{array}$ & $\begin{array}{l}\text { Toxic to cancer } \\
\text { cell line } \\
(100 \mathrm{ng}) \\
\end{array}$ & $\begin{array}{l}\text { Nontoxic } \\
(100 \mathrm{ng})\end{array}$ \\
\hline
\end{tabular}

\section{Conclusion}

*ng=nanogram

In conclusion present study provide a better route for synthesis of 3,5-dibenzyl-4-amino1,2,4-triazole. Its ligand and metal complexes were synthesized to screen against cancer cell lines. On the basis of spectral studies metal complexes were assigned to octahedral geometry and ligand could form only mononuclear complexes due to bulky benzyl group. It is also observed that compound no. 3 in Table 3 i.e. $\mathrm{Ru}$ complex with ligand is a potential anticancer compound in nanogram scale while $\mathrm{Ni}(\mathrm{II})$ and $\mathrm{Cu}(\mathrm{II})$ complexes of ligand were not active against Jurkat and Raji cell lines however they showed cytotoxicity at 50 \& $100 \mathrm{ng}$.

\section{Acknowledgment}

We are thankful to the Department of Science and Technology (DST), Delhi for financial support

\section{References}

1. Loupy A, Ed. Microwaves in organic synthesis, Wiley-VCH Verlag Gmbh \& Co. KGaA: Weinhein, 2002.

2. Caddick S, Tetrahedron, 1995, 51, 10403.

3. Loupy A, Petit A, Hamelin J, Texier-Boullett F, Jacquault P and Mathe D, Synthesis, 1998, 1213.

4. Dundar Y, Cakir B,Kupeli E, Sahin M and Noyanalpan N, Turk J Chem., 2007, 31, 301.

5. Bekircan O and Bektas H, Molecules, 2006, 11, 469-477.

6. Bentiss F, Lagrenee M, Traisnel M and Hornez J C, Corros Sci., 1999, 41, 789.

7. Zajact W W, Siuda J F, Nolan M J and Santossusso T M, J OrgChem., 1971, 36, 3539.

8. Abdel-Rahman M O, Kira M A andTolba M N, Tetrahedron Lett.,1968, 3871.

9. Novinson T, Okabe T, Robins R K and Mattews T R, J Med Chem., 1976, 19, 517-520.

10. Rosenberg B, Camp L V, Troso J E and Mansor V H, Nature (London), 1969, 222, 385.

11. Sigman D S, Graham D R and Aaurora V D, J Biol Chem., 1979, 254, 1269. 
12. Bentiss F, Lagrene M and Barby D, Tetrahedron Lett., 2000, 41, 1539.

13. Koshima H, Hamada M, Tani M, Iwasaki S and Sato F, Heterocycles, 2002, 57, 2145.

15. Mishra L and Jha A, Trans Met Chem., 1993, 18, 559.

16. Mishra L and Jha A, Synth React Inorg Met Org Chem., 1995, 25(4), 601.

17. Raman N, Muthuraj V, Ravichandran S and Kulandaisamy A, Proc Indian Acad Sci (Chem Sci), 2003, 115(3), 161.

18. Mishra L and Jha A and Yadaw A K, Trans Met Chem., 1997, 22, 406. 


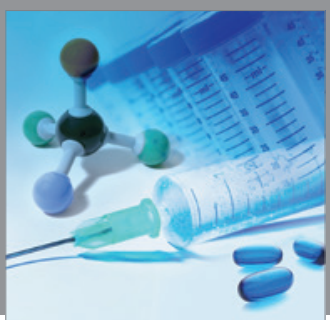

International Journal of

Medicinal Chemistry

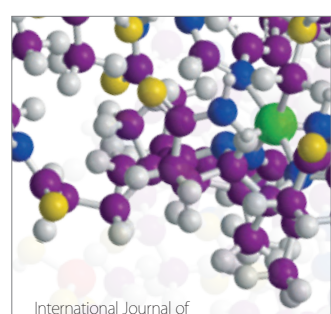

Carbohydrate Chemistry

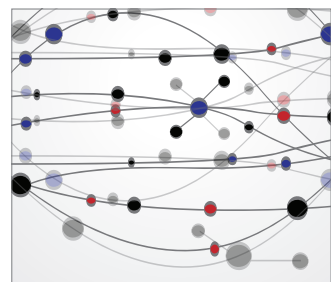

The Scientific World Journal
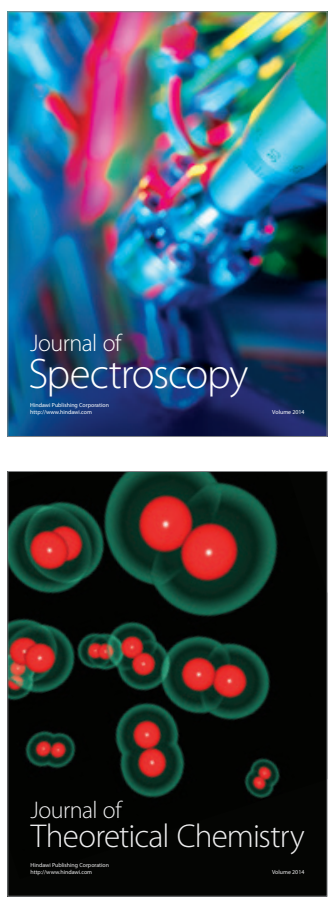
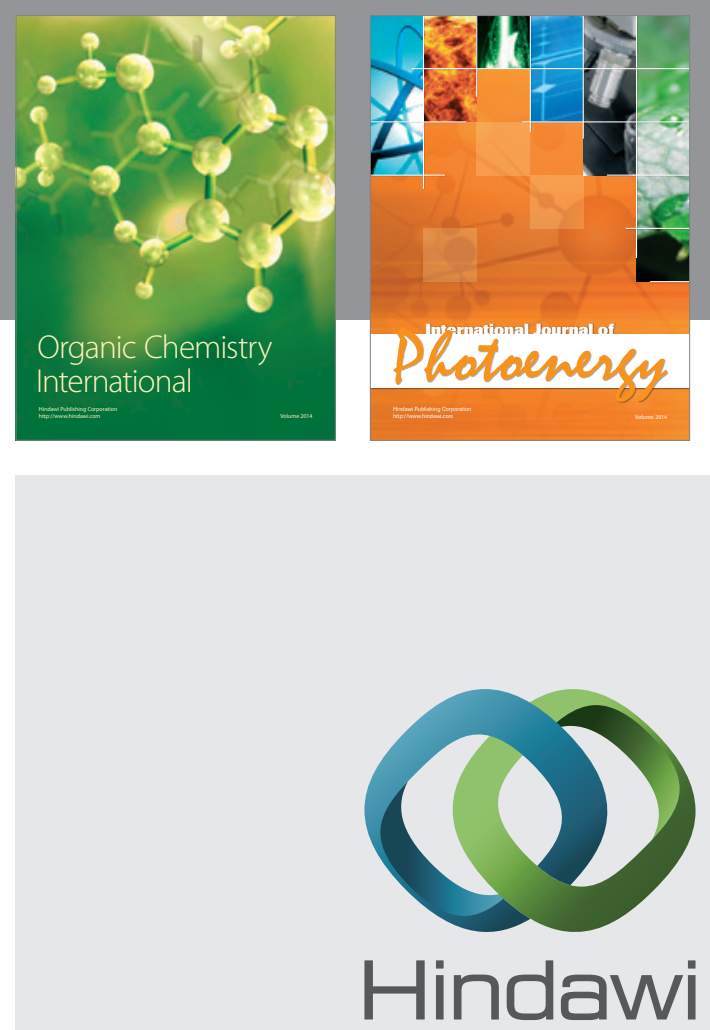

Submit your manuscripts at

http://www.hindawi.com
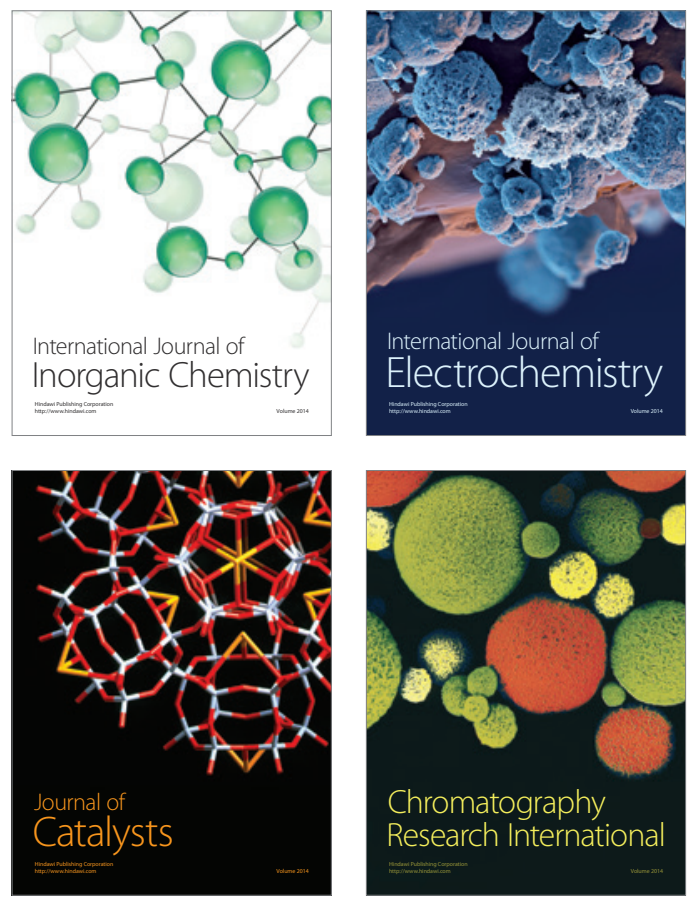
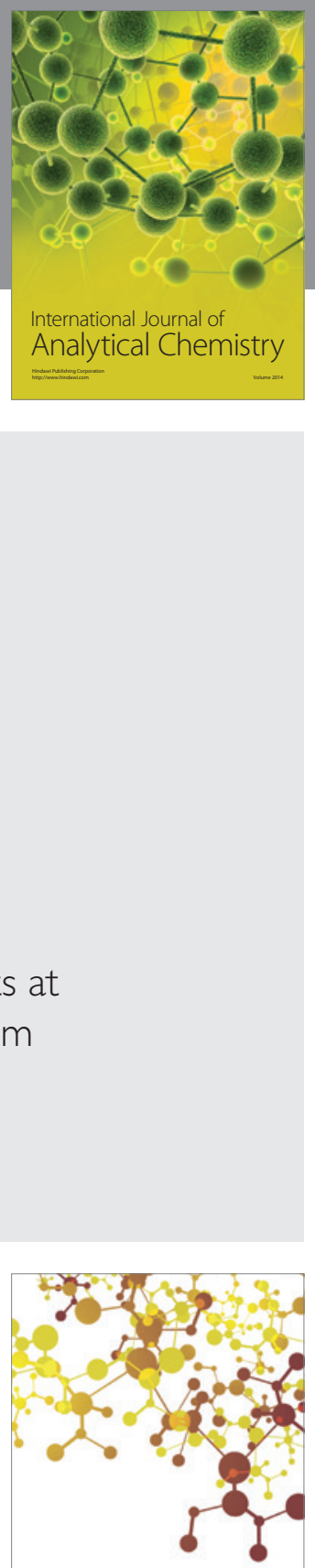

Journal of

Applied Chemistry
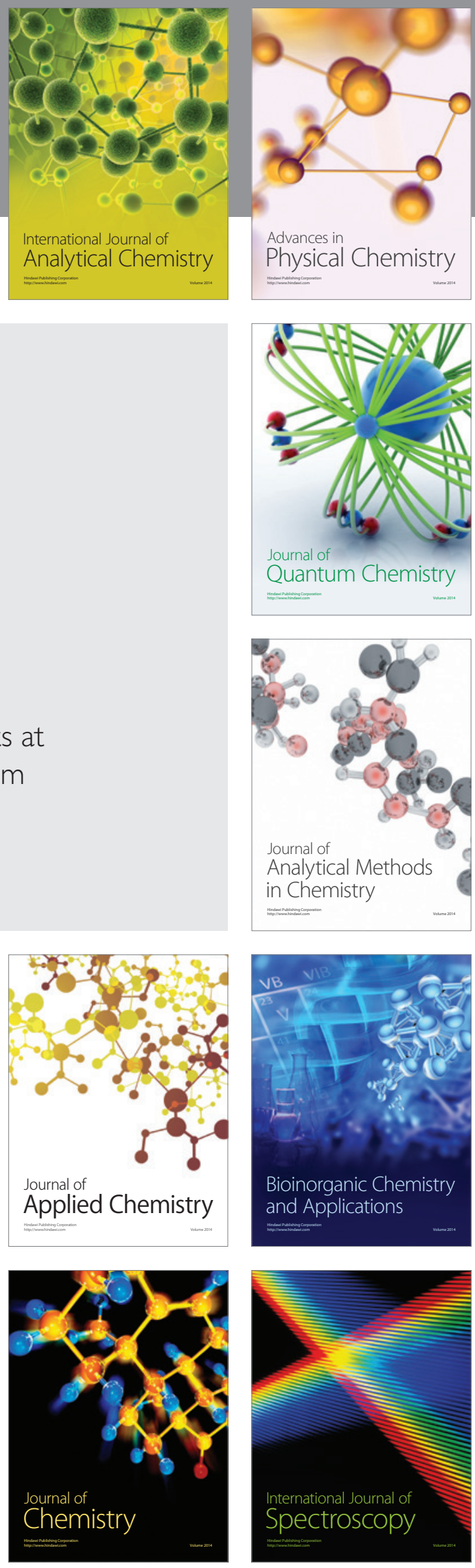